trimester. Hepatitis $\mathrm{E}$ virus also has a much lower rate of secondary spread-about $2 \%$ compared with $15 \%$ observed with hepatitis A virus.

Doctors have long recognised the unusually high mortality associated with "infectious hepatitis" in pregnant women in developing countries, ${ }^{8}$ which provoked debate until the causative virus was recognised as a virus other than hepatitis $A$ virus. Many cases of epidemic hepatitis in pregnant women have apparently resulted in fulminant hepatitis and maternal death, although surviving infants seem to be unaffected. Reasons for this severe infection remain unknown, although a recent paper contests the idea that hepatitis $\mathrm{E}$ virus is the sole cause of liver failure in pregnant women. ${ }^{9}$ The use of specific immunoassays together with the detection of hepatitis $\mathrm{E}$ virus $\mathrm{RNA}$ with the reverse transcriptase polymerase chain reaction should clarify the situation.

A virus that infects by faecal-oral transmission and that affects mainly young adults is unusual. Such viruses usually infect children, often subclinically, and confer lifelong immunity. Early reports suggested that antibodies to hepatitis $\mathrm{E}$ virus may be shortlived so that reinfection is possible, ${ }^{10}$ which would account for the high attack rate in young adults. This explanation becomes less plausible in the light of recent data that indicate that, at least in some cases, antibodies persist. ${ }^{11}$ These antibodies may not be protective; more work is needed to explain this anomaly. In addition, current assays, especially in which antigens from only one strain are represented, may not detect low concentrations of antibody.

This uncertainty over how long antibodies persist makes an evaluation of prevalence based on the presence of antibody difficult to interpret. Recent reports have estimated prevalences from $0.4 \%$ in Dutch blood donors to $16 \%$ in healthy subjects in Hong Kong. Initially, in places where the virus is not endemic, studies to establish the proportion of cases of acute hepatitis that are due to hepatitis $\mathrm{E}$ virus would seem more useful than prevalence studies. We have reported on several patients with acute hepatitis imported into Britain from the Indian subcontinent, ${ }^{12}$ and all cases that we have subsequently identified have been in travellers returning from endemic areas. Other European reports suggest a similar picture.

Routes of transmission other than the faecal route have been suggested. As a transient viraemic stage occurs during the infection, a theoretical possibility exists of transmission by blood. Current evidence does not suggest that this is an important route of infection. ${ }^{13}$

Finally, it is intriguing that a virus that causes so few secondary cases, presumably because of its lability, can cause outbreaks that affect thousands. These epidemics occur only when water supplies are grossly contaminated, which suggests that large doses of the virus are needed to cause disease.

Birmingham Heartlands Hospital,

SUSAN J SKIDMORE

Principal virologist

Birmingham B9 5SS

1 Reyes GR, Purdy MA, Kim JP, Luk K-C, Young LM, Fry KE, et al. Isolation of a cDNA from the virus responsible for enterically transmitted non-A, non-B hepatitis. Science 1990;247: 1335-9.

2 Bradley DW. Hepatitis E: epidemiology, aetiology and molecular biology. Reviews in Medical Virology 1992;2:19-28.

3 Khuroo MS. Study of an epidemic of non-A, non-B hepatitis: possibility of another human virus distinct from post transfusion non-A non-B type. Am $\mathcal{F}$ Med 1980;68:818-24.

4 Balayan MS, Andjaparidze AG, Savinskaya SS, Ketiladze ES, Braginsky DM, Savinor AP, et al. Evidence for a virus in non-A non-B hepatitis transmitted via the faecal oral route. Intervirology 1983;20:23-31.

5 Dawson GJ, Chau KH, Cabal CM, Yarbough PO, Reyes GR, Mushahwar IK. Solid-phase enzymelinked immunosorbent assay for hepatitis $E$ virus IgG and IgM antibodies utilizing recombinant antigens and synthethic peptides. $\mathcal{I}$ Virol Methods 1992;38:175-86.

6 Skidmore SJ, Yarbough PO, Gabor KA, Reyes GR. Hepatitis E virus: the cause of a waterborne hepatitis outbreak. F Med Virol 1992;37:58-60.

7 Khuroo MS, Rustgi VK, Dawson GJ, Mushahwar IK, Yattoo GN, Kamili S, et al. Spectrum of hepatitis $\mathrm{E}$ infection in India. $尹$ Med Virol 1994;43:281-6.

8 Christie AB, Allam AA, Aref MK, El Muntasser IH, El-Nageh M. Pregnancy hepatitis in Libya. Lancet 1976;ii:827-9.

9 Fagan EA, Menon T, Valliammai T, Paul DA, Donati MC, Burroughs AK, et al. Equivocal serological diagnosis of sporadic fulminant hepatitis E in pregnant Indians. Lancet 1994;344: 342-3.

10 Goldsmith R, Yarbough PO, Reyes GR, Fry KE, Gabor KA, Kamel M, et al. Enzyme-linked immunosorbent assay for diagnosis of acute sporadic hepatitis $\mathrm{E}$ in Egyptian children. Lancet 1992;339:328-31.

11 Khuroo MS, Kamili S, Dar MY, Moecklii R, Shahid J. Hepatitis E and long-term antibody status. Lancet 1993;341:1335.

12 Skidmore SJ, Yarbough PO, Gabor KA, Tam AW, Reyes GR, Flower AJE. Imported hepatitis E in UK. Lancet 1991;337:1541.

13 Mannucci PM, Gringeri A, Santagostino E, Romano L, Zanetti A. Low risk of transmission of hepatitis $E$ virus by large-pool coagulation factor concentrates. Lancet 1994;343:597-8.

\title{
Profiting from the NHS
}

\section{The government seems headed for another storm}

The NHS is on the verge of a change that could have profound implications in the longer term. That change goes under the name of the private finance initiative. Its ostensible purpose is to attract private finance to enable NHS trusts to undertake capital projects that might otherwise not be funded. The risk is that in the wrong hands the private finance initiative could make a reality of claims that the provision of NHS services is being privatised.

The private finance initiative affects all parts of the public sector and was launched by the chancellor of the exchequer in 1992. Its aim is to reduce public spending on capital projects by providing incentives for private finance to fund schemes in energy, transport, health, and other sectors. To date the initiative has had only a marginal impact on the NHS, but under arrangements currently being put in place it is likely to have a substantial influence on both the financing and management of health services.

The reason for this is that, under rules established by the Treasury, NHS trusts have to show that they have actively sought private finance before they can be considered for funding through government sources. This means that private finance is now the preferred method of paying for capital projects. In practice, NHS trusts will have to advertise in the official journal of the European Union at the stage when finance is wanted. Only if this approach fails will an NHS trust be eligible to seek finance from the Treasury.

Given that capital raised from the private sector is more expensive than money provided by the Treasury, this has in the past been seen as a theoretical option. However, in an important new twist the emphasis has now been placed on using private finance not only for the cost of new building but also for the provision of associated services. It is this opportunity that makes it attractive for the private sector to become involved in NHS schemes. This is because the efficiency savings available to companies in taking over the running of NHS services will in some cases outweigh the extra cost of borrowing money from the private sector. Commercial companies may also be able to exploit the use of NHS land and 
buildings to generate income in ways that have not hitherto been attempted.

Consequently, private finance will extend well beyond the infrastructure of health care into the direct provision of certain services. This includes not only services that have already been opened up to competitive tendering (such as catering, cleaning, and laundry) but also clinical services (such as radiology and pathology). That would leave the NHS responsible only for the provision of core medical and nursing services, and in some circumstances even these services would be taken on by the private sector. It is this prospect that has transformed what at first seemed a policy of marginal interest into a programme that could, over time, fundamentally alter the NHS.

Extending the private finance initiative into service provision as well as infrastructure has stimulated a great deal of interest on the part of private financiers, construction companies, developers, and companies delivering services. Major schemes are under discussion in places as diverse as Norwich, Edinburgh, Durham, Peterborough, Swindon, London, Coventry, and Worcester. These include projects to build and run entire new hospitals as well as extensions to or developments of existing buildings.

The private finance initiative is in this way beginning to affect the mainstream of NHS provision and is no longer a sideshow focusing on schemes such as car parking, shopping malls, and incinerators. Already special purpose companies are being formed to bring together financial institutions and companies delivering services as lawyers, financial advisers, and consultants search for creative solutions as they scent the prospect of profits from the increasing commercialisation of health care.

Treasury rules require that schemes funded under the private finance initiative involve a genuine transfer of risk to the private sector in order to justify the returns that may be generated. Inevitably the transfer of risk will involve the transfer of control, with private interests taking a direct stake in the assets of trusts and their management. Not only does this entail selling off the family silver but it also involves a much bigger say for the private sector in how trusts are run in future. Those providing private finance and putting their investment at risk will not expect to play a passive part in the management of services, and they will no doubt take a close interest in the appointment and performance of trust managers.

\section{Long pay back}

Whether the private sector is able to realise profits depends on the security of income of NHS trusts that are involved. With substantial schemes requiring partnerships between the public and private sectors over a period of 20 years or more to justify the level of investment, doubt must exist as to whether banks and other institutions will be prepared to accept the degree of risk required by the Treasury. Much will depend on the commitment that purchasers are prepared to make and whether they stand to gain or lose under the resource allocation formula.

A major uncertainty is bound to be the attitude of general practitioner fundholders, who will play a bigger part in purchasing in the light of plans announced recently. ${ }^{1}$ If they are unwilling to give a long term commitment to NHS trusts seeking to raise funds under the private finance initiative then the initiative will be stillborn. Not for the first time, the left hand of government may hamper what the right hand is seeking to achieve.

Much will also depend on the political future. At this stage, Labour party policy does not officially endorse the private finance initiative, although Labour's fiscal conservatives seem as much in favour of the initiative as their Tory counterparts. ${ }^{2}$ This may make sense in relation to infrastructure projects in areas such as energy and transport but is more difficult to understand in a field as politically sensitive as health care. The same logic applies to Virginia Bottomley, who clearly distanced herself last summer from arguments that NHS trusts should be privatised and who has shown no appetite to support the more radical aspirations of some of her cabinet colleagues. Public reaction to a policy which seems to be leading to privatisation through the back door is not difficult to predict, and it is therefore all the more surprising that this policy should be pursued with a general election in the offing.

Politics aside, technical questions also arise. These have been highlighted by the Economist, a journal that would normally be expected to support policies to increase the role of private provision and to break down public sector monopolies. In a trenchant critique the Economist described the private finance initiative as a "scam" and a "deceit," providing "a boon only for politicians and those businessmen keen to profit from the public purse." This is because the use of private finance obscures the true state of the government's finances while at the same time increasing the price the government pays for its capital. It might be added that implementing the initiative will involve huge transaction costs as lawyers, financial advisers, and others are hired to advise NHS trusts seeking funds in this way. Whether the efficiency gains expected from the initiative will compensate for these costs remains to be shown.

The suspicion remains that in this case health policy is being driven from the Treasury, with health ministers either powerless or reluctant to intervene. Yet with an election in sight, the fears of the public and the claims of the government's critics will only be accentuated by the application of the private finance initiative in its present form within the NHS. At its worst, this could undo all of the progress made since 1991 in using the separation of purchaser and provider roles to improve health and health services and it could destroy the opportunity to develop a bipartisan approach to taking the reforms forward. Ministers should clarify their intentions at the earliest opportunity or prepare for the barrage of criticism that will inevitably follow.

CHRIS HAM Director

Health Services Management Centre,

University of Birmingham,

Birmingham B15 2RT

$1 \mathrm{Ham} C$. The future of purchasing. $B M \mathcal{F}$ 1994;309:1032-3.

2 Brown G, Cook R, Prescott J. Financing infrastructure investment. London: Labour Party, 1994.

3 Mr Clarke's Free Lunch. Economist 1995 Jan 28:18. 